Case report

\title{
PRIAPISM FOLLOWING hCG ADMINISTRATION IN A CAT
}

\author{
QUARANTA Giuseppe ${ }^{1}$, ROTA Ada ${ }^{1 *}$, DOGLIERO Andrea ${ }^{1}$, PECCHIA Flaviana ${ }^{2}$ \\ ${ }^{1}$ Dipartimento di Scienze Veterinarie, Grugliasco, Torino, Italia \\ ${ }^{2}$ Practitioner, Centro Veterinario Specialistico, Roma, Italia
}

(Received 14 May; Accepted 8 September 2015)

\begin{abstract}
Priapism, defined as a persistent and painful penile erection in the absence of sexual excitation, is an uncommon disorder of cats that usually requires penile amputation and perineal urethrostomy. This report describes a case of priapism in a short-haired Persian male cat aged 3 years. The condition had appeared after attempted mating with a female at the end of oestrus and the time of referral to the authors was 10 days after onset. Previous treatment had consisted of corticosteroids and local lubricants. On physical examination, the cat appeared bright and alert; the penis was erect but the colour was normal; blood analysis excluded viral pathologies. The cat history revealed that he had been treated with 500 IU hCG i.m. because he had to mate with three queens in a short period of time. In consideration of the mild symptoms, conservative treatment was adopted. The condition resolved in about 40 days. This is the first report of priapism following hCG administration in a cat and indicates that the misuse of this gonadotropin might cause potentially harmful side effects.
\end{abstract}

Key words: cat, priapism, hCG, conservative treatment

\section{INTRODUCTION}

Priapism, defined as a persistent and painful penile erection in the absence of sexual excitation, is an uncommon disorder in cats [1]. Erectile tissue engorgement can either be the consequence of an increase in arterial blood flow or of a reduction in venous drainage: in man, the high-flow (arterial) priapism is almost always the consequence of trauma to the perineum or penis, while the low-flow (veno-occlusive) priapism can be idiopathic or secondary to haematologic disorders, prostatic diseases, spinal cord trauma, pharmacological agents [2]. Low-flow (ischemic) priapism is more prevalent than high-flow (nonischemic) priapism in man and has a worse prognosis [3]. Stagnation of blood leads to thrombosis of the cavernous spaces, and corporal ischemia lasting more than 24 hours leads to necrosis of smooth muscle and nerves and irreversible penile fibrosis with permanent erectile dysfunction after 48 hours [3].

Corresponding author: e-mail: ada.rota@unito.it 
Priapism has so far been reported only in ten cats, some of which neutered: in all ten cases low-flow priapism was diagnosed and the causes included trauma following attempted mating, spinal trauma, genitourinary infection or inflammation, vasculitis following feline infectious peritonitis [1,4-6].

\section{CASE PRESENTATION}

A short-haired Persian male cat, aged 3 years, was referred for a condition of persistent penile erection that had appeared 10 days previously, after attempted mating with a queen at the end of the oestrus period.

The cat had immediately been visited in emergency and a diagnosis of priapism of neurologic/traumatic origin had been formulated. A short-acting corticosteroid (injectable prednisolone) was administered and prescribed for 5 days $(1 \mathrm{mg} / \mathrm{kg}$ SID) followed by a tapering schedule (alternate day administration for 5 times and alternate day half-dosage administration for 5 times); in addition, local application of lubricants was prescribed. Subsequent neurologic and orthopedic examinations did not show any abnormality, so that spinal or pelvis trauma were deleted from the list of possible causes; also urinary tract pathologies were excluded after urethral catheterisation and urinalisys.

When was referred to the authors, the cat looked bright, alert and comfortable, was reported to eat normally and not to show excessive licking of the penis. On clinical examination, the penis appeared protruding from the prepuce and was erect, although no signs of inflammation were present and the surface was not dry (Fig. 1); palpation did not elicit pain; urination was normal.

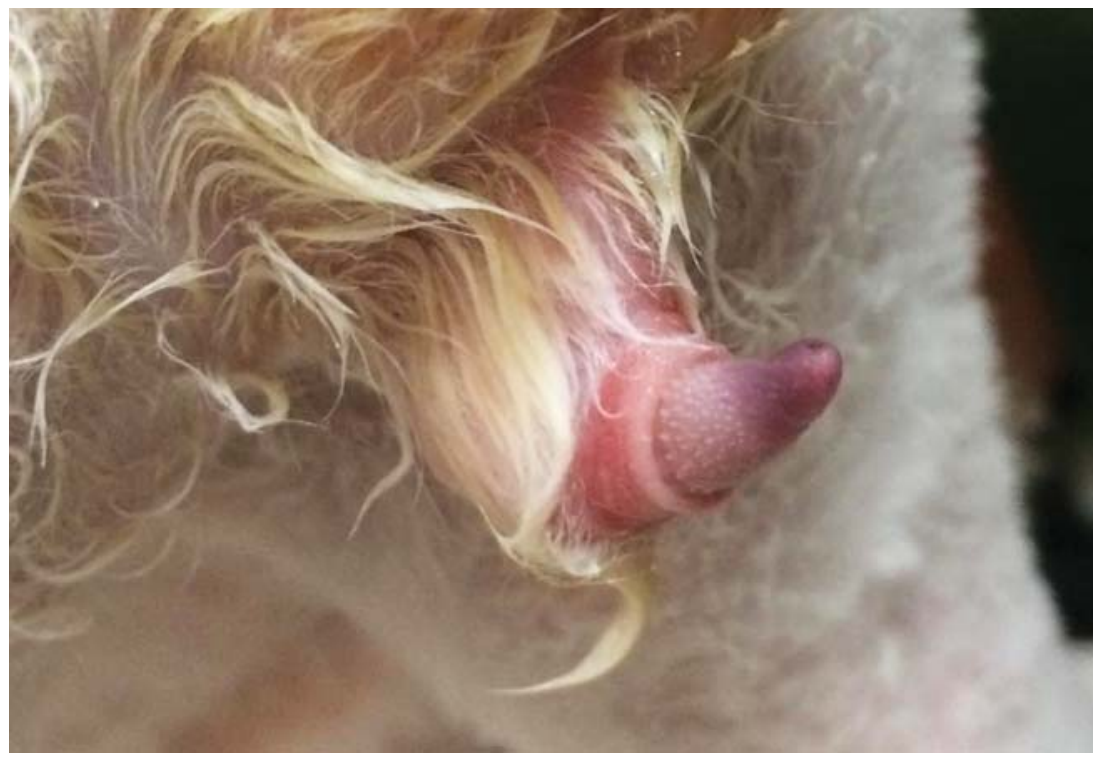

Figure 1. Partially erect cat penis: mucosa colour appears normal 
A blood sample was collected for complete analysis and serum protein electrophoresis: the mild alterations found in white blood cell number and hepatic enzymes concentration could be a consequence of the corticosteroid treatment. FIP was excluded as a possible causative factor because total serum protein content and protein electrophoresis were normal.

In consideration of the anomalous benign course of the condition, and of the exclusion of the known possible causes, the owner was asked again whether anything had been administered to the cat and this time he remembered having treated him with hCG (500 UI, i.m. Corulon $®)$, as suggested by a breeder, since the cat was going to mate with three queens in a short period of time.

The mild symptoms and the detection of the supposed causative agent (hCG) suggested that the condition could be managed with local medications only. After about 40 days from the onset, symptoms had progressively disappeared, the penis was again contained within the prepuce and the cat was again able to mate.

Conservative treatment for priapism in the cat is generally unsuccessful and the condition is resolved with penile amputation and perineal urethrostomy because of pain, difficult urination, mucosal congestion and penis tip necrosis. In a single case the corpora cavernosa were drained after tunica albuginea incision and irrigated with heparinized saline, and the penis returned to its normal state; however, since the cat had been neutered, erectile functionality could not be assessed [4].

Exogenous gonadotropins are usually administered to cats for ovarian-stimulatory effects in the case of artificial insemination or in vitro fertilization procedures: the pharmacokinetics of hCG has been evaluated only in queens, together with the ovarian-stimulatory effect [7]. After intramuscular administration of $75 \mathrm{IU}$, hCG was detectable for at least $96 \mathrm{~h}$ and its half-life was $22.9 \pm 4.1 \mathrm{~h}$. Estradiol concentration increased above basal levels $24-72 \mathrm{~h}$ after hCG administration, reached peak values by 120-144 h, and then declined to baseline by $168 \mathrm{~h}$ [7]. There are no studies on male cats. In two pony stallions testosterone concentrations were markedly elevated for five days after injection of 6,000 IU hCG [8]. The extremely high dosage administered to the male cat could be the reason for the prolonged yet transitory effect.

Although the temporal association between hCG administration and development of priapism does not prove the gonadotropin causative role, and the condition had been previously reported also in neutered cats, the fact that our case is the only one reported in which the condition resolved increases the likelihood of causality.

This report could in any case be useful to emphasize the necessity of treating the animals with a correct hCG dosage, if necessary, in order to prevent potentially harmful side effects. 


\section{REFERENCES}

1. Gunn-Moore DA, Brown PJ, Holt PE, Gruffydd-Jones TJ: Priapism in seven cats. J Small Anim Pract 1995, 36:262-266.

2. Rochat MC: Priapism: a review. Theriogenology 2001, 56:713-722.

3. Bivalacqua TJ, Burnett AL: Priapism: new concepts in the pathophysiology and new treatment strategies. Curr Urol Rep 2006, 7:497-502.

4. Orima H, Tsutsui T, Waki T, Kawakami E, Ogasa A: Surgical treatment of priapism observed in a dog and a cat. Jpn J Vet Sci 1989, 51:1227-1229.

5. Rota A, Paltrinieri S, Jussich S, Ubertalli G, Appino S: Priapism in a castrated cat associated with feline infectious peritonitis. J Feline Med Surg 2008, 10:181-184.

6. Swalec KM, Smeak DD: Priapism after castration in a cat. J Am Vet Med Assoc 1989, 195:963-964.

7. Swanson WF, Wolfe BA, Brown JL, Martin-Jimenez T, Riviere JE, Roth TL, Wildt DE: Pharmacokinetics and ovarian-stimulatory effects of equine and human Chorionic Gonadotropins administered singly and in combination in the domestic cat. Biol Reprod 1997, 57:295-302.

8. Cox JE, Redhead PH: Prolonged effect of a single injection of human chorionic gonadotrophin on plasma testosterone and oestrone sulphate concentrations in mature stallions. Equine Vet J 1990, 22:36-38.

\section{PRIAPIZAM KOD MAČKA NAKON PRIMENE hCG}

\section{QUARANTA Giuseppe, ROTA Ada, DOGLIERO Andrea, PECCHIA Flaviana}

Priapizam, definisan kao perzistentna i bolna erekcija penisa u odsustvu seksualne ekscitacije, je redak poremećaj kod mačora koji obično zahteva amputaciju penisa ili perinealnu uretrostomu. Ovaj rad opisuje slučaj priapizma kod kratkodlakog persijskog mačora starosti 3 godine. Navedeno stanje je nastalo nakon pokušaja parenja sa ženkom pri kraju estrusa. Vlasnici su se obratili za stručnu pomoć 10 dana nakon nastanka simptoma. Predhodna terapija se sastojala u primeni kortikosteroida i lokalno lubrikanata. Tokom kliničkog pregleda mačor je bio budan i u svesnom stanju, penis je bio u erekciji i normalne boje. Analize krvi su isključile postojanje virusne etiologije. Anamneza je pokazala da je mačor tretiran sa 500 IU hCG i.m., s obzirom na to da je morao da se pari sa tri ženke tokom kratkog vremenskog perioda. Uzimajući u obzir blagu simptomatologiju, opredelili smo se za konzervativnu terapiju. Stanje se popravilo nakon 40 dana. Ovaj rad predstavlja prvi izveštaj priapizma nakon aplikacije hCG mačoru i ukazuje da zloupotreba ovog gonadotropina može da ima potencijalno štetne nuspojave. 